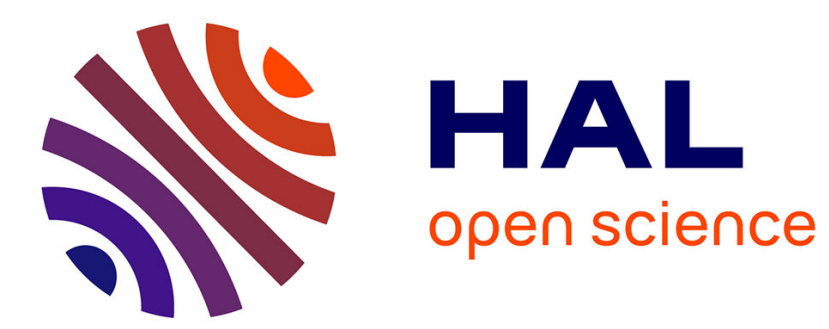

\title{
Esterase activity of dairy Propionibacterium
}

C Dupuis, P Boyaval

\section{To cite this version:}

C Dupuis, P Boyaval. Esterase activity of dairy Propionibacterium. Le Lait, 1993, 73 (4), pp.345-356. hal-00929346

\section{HAL Id: hal-00929346 https://hal.science/hal-00929346}

Submitted on 1 Jan 1993

HAL is a multi-disciplinary open access archive for the deposit and dissemination of scientific research documents, whether they are published or not. The documents may come from teaching and research institutions in France or abroad, or from public or private research centers.
L'archive ouverte pluridisciplinaire HAL, est destinée au dépôt et à la diffusion de documents scientifiques de niveau recherche, publiés ou non, émanant des établissements d'enseignement et de recherche français ou étrangers, des laboratoires publics ou privés. 


\title{
Original article
}

\section{Esterase activity of dairy Propionibacterium}

\author{
C Dupuis, P Boyaval * \\ Laboratoire de Recherche de Technologie Laitière, INRA, 65 rue de Saint-Brieuc, \\ 35042 Rennes Cedex, France
}

(Received 17 March 1993; accepted 2 June 1993)

\begin{abstract}
Summary - This paper reports results on the esterolytic activity of dairy Propionibacterium. All the species present an active esterolytic system on naphthyl substrates for fatty acids which contain < 10 carbons. Between 1 to 4 activities of different specificities were revealed on non-denaturing polyacrylamide gel electrophoresis for each species. These activity patterns could be very useful in differentiating between a few Propionibacterium species. Ion-exchange chromatography allowed 3 main esterase activities to be separated on a concentrated intracellular extract of $P$ freudenreichii subsp freudenreichii. These activities have very different substrate specificities which agree closely with those determined by electrophoresis.
\end{abstract}

esterase / Propionibacterium / fatty acid / lipolysis / cheese

Résumé - Activités estérasiques des bactéries propioniques. Les activités estérasiques des bactéries propioniques laitières ont été étudiées. Toutes les espèces possèdent des activités estérasiques significatives sur des dérivés naphtyl d'acides gras contenant jusqu'à 10 atomes de carbone. De une à 4 activités de spécificités différentes ont été mises en évidence pour chacune des espèces. Ces profils d'activités pourraient être un outil de différenciation de certaines espèces de Propionibacterium. Une prépurification par chromatographie d'échange d'ions d'extraits intracellulaires de $\mathrm{P}$ freudenreichii subsp freudenreichii a permis de révéler 3 activités distinctes, de spécificités très différentes, en parfait accord avec la mise en évidence d'activité enzymatique sur gel d'électrophorèse.

estérase / Propionibacterium / acide gras / lipolyse / fromage

- Correspondence and reprints 


\section{INTRODUCTION}

Propionic acid bacteria play important roles in many industrial processes: production of propionic acid used as a natural preservative in baking products (Boyaval and Corre, 1987); production of vitamin $B_{12}$ and involvement in the development of the characteristic flavor and eye production in Swiss-type cheeses (Hettinga and Reinbold, 1972). Proteolysis and lipolysis are the key mechanisms in Swiss cheese ripening (Biede et al, 1979). Fat breakdown is apparently essential to the development of flavor (Ohren and Tuckey, 1965) and it is well-known that ripened Swiss cheese contains more free fatty acids than many other similar hard-ripened cheeses, including Cheddar (Oterholm, 1967). According to Lawrence (1967), it is obvious that large numbers of weakly lipolytic organisms may play an important role in products with a long storage life, such as cheese.

Even if propionic acid bacteria predominate in this type of cheese during ripening, their role in the formation of monocarboxylic acids from triglycerides has not been completely investigated and the results differ widely from one study to another. Propionic acid bacteria seem to be rather deficient in enzymes able to hydrolyze the phospholipid-protein complex of the fat globules in milk (Umanskii et al, 1974). Nevertheless, $65 \%$ of the strains of Propionibacterium shermanii tested by Umanskii and Borovkova (1979) presented a strong lipolytic activity. This strong nonspecific activity had already been noticed by Kaderavek et al (1973). Knaut and Mazurek (1974) found low lipolytic activities in 10 strains of propionibacteria. Werner (1967) found no extracellular lipase activity in 8 strains, but Cantoni et al (1966) demonstrated that propionic acid bacteria could produce butyric acid from tributyrin and free fatty acid from butterfat. Moreo- ver, a glycerol ester hydrolase activity (EC 3.1.1.3.) was brought to light in $P$ freudenreichii subsp shermanii (Oterholm et al, 1970a). This enzyme preferentially hydrolyzed substrates in emulsion, but also showed some esterase activity (Oterholm et al, 1970b).

In this study, the esterolytic activity of the 4 species of propionic acid bacteria involved in hard cheese technology was examined. In line with most published papers, we have chosen to use the term esterase for acylglycerol hydrolases preferentially hydrolyzing esters in true solution (in contrast, lipase preferentially hydrolyzes glycerol esters in emulsion).

\section{MATERIALS AND METHODS}

\section{Strains}

Five strains, described as the type strain by Cummins and Johnson (1986), of each species or subspecies of dairy Propionibacterium were used during this study: $P$ freudenreichii subsp freudenreichii CIP 103026 (Collection de I'Institut Pasteur, Paris, France), $P$ freudenreichii subsp shermanii CIP 103027, $P$ jensenii CIP 103028 , $P$ thoenii CIP 103029 and $P$ acidipropionici DSM 4900 (Deutsche Sammlung von Mikroorganismen und Zellkulturen, Braunschweig, Germany).

\section{Media and growth conditions}

Stock cultures were maintained at $-70^{\circ} \mathrm{C}$ in a yeast extract-lactate medium (YEL) (Malik et al, 1968) containing $15 \%(\mathrm{v} / \mathrm{v})$ glycerol (Prolabo, France). All media were sterilized by heat treatment $\left(120^{\circ} \mathrm{C}\right.$ for $\left.15 \mathrm{~min}\right)$. Two transfers at $1 \%$ (v/v) $\left(48 \mathrm{~h}\right.$ incubation at $\left.30^{\circ} \mathrm{C}\right)$ were performed on YEL before actual use. Cells were grown in a $1-1$ bottle of $\mathrm{YEL}$ at $30^{\circ} \mathrm{C}$. Bacterial growth was monitored by optical density (OD) measurements $(650 \mathrm{~nm})$ (Beckman spectrophotometer DU7400, USA). Calibration between OD and to- 
tal proteins, and OD and population were carried out. Cells from the middle of the exponential growth phase were harvested by centrifugation (Cryofuge M7000, Heraeus, Germany) for 20 min at $7000 \mathrm{~g}, 4^{\circ} \mathrm{C}$. They were washed once with cold sterilized distilled water and tested after disruption for esterase activity.

\section{Protein determination}

A folin-phenol reagent was used to determine the protein content of samples with bovine serum albumin (Sigma, USA) as standard (Lowry et al, 1951).

\section{Preparation of cell-free extracts}

Washed cell pellets were frozen at $-18^{\circ} \mathrm{C}$ overnight, and then resuspended in sterilized distilled water at $10^{11} \mathrm{CFU} \cdot \mathrm{ml}^{-1}$. Cells were disrupted using a French Pressure Cell Press (SLM Aminco, USA) for $15 \mathrm{~min}$ at 15600 Psi. This treatment was repeated twice. Preliminary centrifugation on a J2HS (Beckman, USA) for 15 min at $3840 \mathrm{~g}, 4^{\circ} \mathrm{C}$ allowed the removal of unbroken cells. Another centrifugation for $20 \mathrm{~min}$ at $39200 \mathrm{~g}, 4^{\circ} \mathrm{C}$ separated the intracellular fraction (supernatant) from the parietal fraction (containing both cell walls and membranes). The intracellular fraction was kept at $-18^{\circ} \mathrm{C}$ until use. The parietal fraction was washed 3 times in distilled water and then kept in pellet form at $-18^{\circ} \mathrm{C}$.

\section{Esterase assay}

A survey of esterase activity was made with the API ZYM system (LRA ZYM strips, Bio Mérieux, France). Ten substrates were tested (from 2naphthyl-butyrate to 2-naphthyl-stearate) on intracellular and parietal fractions and on whole cell suspensions. These suspensions were obtained as follows: cells from the middle of the exponential growth phase were washed twice in sodium phosphate buffer $0.05 \mathrm{~mol}^{-1} \mathrm{pH} 7.0$, and the $O D(650 \mathrm{~nm})$ was adjusted to 1.0 before application on the strips. The strips were then incubated at $30^{\circ} \mathrm{C}$ and read after $4 \mathrm{~h}$.
The esterase activity was quantified using $\beta$ and $\alpha$-naphthyl ( $\mathrm{Na}$ ) derivatives of acetate, propionate and butyrate (Sigma, USA) as substrates according to the method of Goldberg and Rutenburg (1958) modified as follows. Enzymatic reaction occurred in microplates (Nunc Immuno Plate Maxisorp, Denmark) at $30^{\circ} \mathrm{C}$ for 10,30 and $60 \mathrm{~min}: 50 \mu \mathrm{l}$ substrate ( $\mathrm{Na}$ derivatives 0.66 $\mathrm{mmol} \cdot \mathrm{I}^{-1}$, dissolved in acetone $(5 \% \mathrm{v} / \mathrm{v})$ in sodium phosphate buffer $0.05 \mathrm{~mol}^{-1}, \mathrm{pH} 7.0$ ) were added to $50 \mu$ of the enzyme solution. The reaction was stopped by $50 \mu \mathrm{l}$ of 'Zym A' TRRIShydroxymethyl-aminoethane $25 \%$ (w/v), $12.5 \mathrm{~N}$ hydrochloric acid $11 \%(\mathrm{v} / \mathrm{v})$ and sodium lauryl sulfate (SDS) $10 \%(\mathrm{w} / \mathrm{v})]$. Then the reaction was revealed with $50 \mu \mathrm{l}$ of 'Zym B' (Fast Blue BB (Sigma, USA) $0.35 \%$ (w/v) in 2-methoxy-ethanol (Prolabo, France)). Absorbance was immediately determined at $540 \mathrm{~nm}$ on a microplate autoreader EL309 (Bio-Tek Instruments, USA). A unit $(U)$ of enzyme specific activity was expressed as the change of 0.1 unit absorbance per min for $1 \mathrm{mg}$ of bacterial proteins present in the tested fraction. For myristate, palmitate and stearate fatty acids, the substrate mixture was prepared as described by Gomori (1953): $10 \mu \mathrm{l}$ of $\alpha$ and $\beta \mathrm{Na}$ derivative stock solutions (52.8 mmol.1-1 in acetone) were added to $790 \mu \mathrm{l} 1,2$ propanediol $(4 \mathrm{~N})$ in distilled water and used as previously described.

Esterase patterns after fractionation of intracellular fractions on polyacrylamide gel electrophoresis (PAGE) were performed on Protean II xi cell (Bio Rad, USA) using an ECPS $3000 / 150$ generator (LKB-Pharmacia, Netherlands). The gel $(12 \times 17 \mathrm{~cm})$ was made up without SDS using a $5 \%$ stacking gel in TRIS buffer (Merck, Germany) $0.062 \mathrm{~mol}^{-1}$, $\mathrm{pH} 6.8$ and a $10 \%$ running gel in TRIS buffer $0.33 \mathrm{~mol}^{-1}, \mathrm{pH}$ 7.8. The running buffer was composed of TRIS 0.049 $\mathrm{mol} \cdot \mathrm{H}^{-1}$, and glycin $0.038 \mathrm{~mol} \cdot \mathrm{H}^{-1}, \mathrm{pH} 8.0$. Migration was conducted at $150 \mathrm{~V}, 50 \mathrm{~mA}$ at $4^{\circ} \mathrm{C}$.

Intracellular fractions were concentrated on Centriflo Membrane Cones CF25 (Amicon, USA), and samples containing $1 \mathrm{mg}$ proteins were loaded using bromophenol blue as tracking dye. Gels were stained according to the method of Harper et al (1980): the gel was washed for $5 \mathrm{~min}$ in sodium phosphate buffer 0.1 $\mathrm{mol} \cdot \mathrm{H}^{-1}, \mathrm{pH} 7.0$, then incubated for $30 \mathrm{~min}$ at $30^{\circ} \mathrm{C}$ in $1 \mathrm{ml}$ substrate solution ( $\alpha$ and $\beta \mathrm{Na}$ derivative, $1 \%(w / v)$ in acetone) and $50 \mathrm{ml}$ revealing solution (Fast Red TR (Serva, Germany) $10 \%(w / v)$ in sodium phosphate buffer 0.1 
$\mathrm{mol} \cdot \mathrm{I}^{-1}, \mathrm{pH}$ 7.0). Active esterase bands were dark orange and were characterized by their relative mobility $\left(R_{f}\right)$ values. Acetate- $\beta \mathrm{Na}$, propionate- $\alpha \mathrm{Na}$, butyrate- $\alpha \mathrm{Na}$, valerate- $\alpha \mathrm{Na}$, caproate- $\alpha \mathrm{Na}$, caprylate- $\alpha \mathrm{Na}$, caprate- $\alpha \mathrm{Na}$, laurate- $\alpha \mathrm{Na}$, myristate- $\alpha \mathrm{Na}$, palmitate- $\alpha \mathrm{Na}$, stearate- $\beta \mathrm{Na}$ from Sigma (USA) were used as substrates.

\section{Purification stage}

Twenty-five $\mathrm{ml}$ of intracellular fraction of $P$ freudenreichii subsp freudenreichii containing 4.5 $\mathrm{mg}$ proteins were applied to a Mono Q HR 5/5 column (Pharmacia, Sweden) equilibrated with TRIS-HCl buffer $50 \mathrm{mmol}^{-1} \mathrm{I}^{-1}, \mathrm{pH} 7.5$. Elution was performed at a flow rate of $1 \mathrm{ml} \cdot \mathrm{min}^{-1}$ with a 4-step linear gradient of $\mathrm{NaCl}: 0$ to $0.3 \mathrm{~mol} \cdot \mathrm{I}^{-1}$ for $58 \mathrm{~min}, 0.3$ to $1 \mathrm{~mol}^{-1}$ for $2 \mathrm{~min}$, stationary phase for $10 \mathrm{~min}$ and 1 to $0 \mathrm{~mol} \cdot \mathrm{I}^{-1}$ for $2 \mathrm{~min}$. Detection was performed at $280 \mathrm{~nm}$. Esterase activity was tested on elution fractions $(1 \mathrm{ml})$ as previously described, using acetate- $\beta \mathrm{Na}$, propionate- $\alpha \mathrm{Na}$ and butyrate- $\alpha \mathrm{Na}$ as substrates.

\section{RESULTS}

\section{Screening of esterase activity}

The results of the screening, using API ZYM strips, are shown in table I. Activities were found in all the species of propionibacteria, in whole cells (Cell), intracellular (Intra) and parietal (CW) fractions. A decreased activity with extending chain length substrate was globally exhibited in all strains. As a general rule, activity disappeared or was very slight when chain length of fatty acids exceeded 10 carbons (caprate- $\mathrm{BNa}$ ). A slight activity (grade of colour intensity: 1) was shown by whole cells of $P$ freudenreichii subsp shermanii CIP 103027, $P$ jensenii CIP 103028 and $P$ acidipropionici DSM 4900 , and by intracellular fraction of DSM 4900, when stearate$\mathrm{BNa}$ (carbon number: 18) was used as substrate. Most of the highest activity values were shown by intracellular fractions, whereas the difference between parietal fractions and whole cells was less evident. For most of the substrates, parietal fraction activities of $P$ freudenreichii subsp freudenreichii CIP 103026 were stronger than whole cells activities. $P$ thoenii CIP 103029 and $P$ jensenii CIP 103028, however, showed the opposite trend and $P$ acidipropionici DSM 4900 and $P$ freudenreichii subsp shermanii CIP 103027 were quite similar.

\section{Quantitative activities of intracellular fractions}

With the exception of DSM 4900, all intracellular fractions were active on acetate$\beta \mathrm{Na}$, propionate- $\alpha \mathrm{Na}$ and butyrate- $\alpha \mathrm{Na}$ (fig 1). $P$ jensenii CIP 103028 had a singular pattern of activity, showing the highest specific activity value (4.6 units) on acetate- $\beta \mathrm{Na}$. However, the esterase activity of this strain decreased as chain length extended. The opposite pattern was shown by $P$ thoenii CIP 103029. Another pattern was common to $P$ freudenreichii subsp shermanii CIP 103027, $P$ freudenreichii subsp freudenreichii CIP 103026 and $P$ acidipropionici DSM 4900: activity was at a maximum when using propionate- $\alpha \mathrm{Na}$ as substrate.

\section{Esterase electrophoresis patterns}

Seven distinct active bands, with $R_{\mathrm{f}}$ values ranging from 0.85 to 0.40 , were revealed on the electrophoretic patterns of the 5 strains of Propionibacterium (table II). Each strain possessed from 1 to 4 esterase activities. Three trends could be noticed:

- $P$ freudenreichii subsp freudenreichii CIP 103026 and $P$ freudenreichii subsp sher- 
Table I. Screening on LRA ZYM strips of esterase activity on whole cells, intracellular and parietal fractions, of 5 species of dairy Propionibacterium.

Screening des activités estérasiques sur galeries API ZYM, des cellules entières, des fractions intracellulaires et pariétales de 5 espèces de bactéries propioniques laitières.

$\begin{array}{lllllllllllll}\text { Strains } & \begin{array}{l}\text { Tested } \\ \text { fraction }\end{array} & C 4 & C 5 & \text { C6 } & \text { C8 } & \text { C9 } & \text { C10 } & \text { C12 } & \text { C14 } & \text { C16 } & \text { C18 }\end{array}$

P freudenreichii CIP 103026

$\begin{array}{lllllllllll}\text { Cell } & +++ & ++ & + & + & + & - & - & - & - & - \\ \text { Intra } & ++++ & +++ & +++ & +++ & ++ & + & + & - & - & - \\ \text { CW } & +++ & +++ & +++ & +++ & + & + & - & - & - & -\end{array}$

P shermanii CIP 103027

$\begin{array}{llllllllll}\text { Cell } & +++ & +++ & ++ & ++ & ++ & - & - & - & - \\ \text { Intra } & ++++ & +++ & +++ & +++ & ++ & + & - & - & - \\ \text { CW } & +++ & +++ & ++ & ++ & - & - & - & - & -\end{array}$

$P$ jensenii CIP 103028

$\begin{array}{lllllll}\text { Cell } & +++ & ++ & ++ & + & + \\ \text { Intra } & ++++ & +++ & +++ & +++ & ++ & + \\ \text { CW } & + & +++ & +++ & +++ & +++ & +\end{array}$

\section{$P$ thoenii CIP 103029}

$\begin{array}{llllll}\text { Cell } & ++++ & +++ & +++ & ++ & ++ \\ \text { Intra } & ++++ & +++ & +++ & ++ & + \\ \text { CW } & ++ & ++ & + & + & +\end{array}$

$P$ acidipropionici DSM 4900

$\begin{array}{llllllllll}\text { Cell } & +++ & ++ & ++ & + & + & + & - & - & - \\ \text { Intra } & ++++ & +++ & +++ & +++ & +++ & + & - & - & - \\ \text { CW } & +++ & ++ & ++ & ++ & + & + & - & - & -\end{array}$

A grade (scale from $O$ to 5) was attributed for activity: -: no activity; from + to +++++: intensity from grade 1 (low) to grade 5 (high). * $\beta$ - Naphtyl derivatives: C4, butyrate-; C5, valerate-; C6, caproate-; C8, caprylate-; C9 nonanoate; C10, caprate-; C12, laurate-; C14, myristate-; C16, palmitate-; C18 stearate; Cell: whole cells; Intra: intracellular fraction; CW: cell wall fraction

Une note de 1 à 5 était attribuée aux activités détectées selon l'intensité de la couleur: -: pas d'activité; de + à ++++ : intensité faible (note 1) à forte (note 5); * dérivés $\beta$ - naphtyl: C4, Butyrate-; C5, valérate-; C6, caproate-; C8, caprylate-; $C 9$ nonanoate; $C 10$, caprate-; $C 12$ laurate-; $C 14$, myristate-; $C 16$, palmitate-; $C 18$, stéarate; Cell : cellules entieres; Intra : fractions intracellulaires; $C W$ : fractions pariétales.

manii CIP 103027 had similar patterns: 3 esterase bands, $E_{1}, E_{2}, E_{3}$, were common to these strains only $\left(R_{\mathrm{f}} 0.85,0.62\right.$ and 0.47 ). $E_{1}$ was only active (high activity) on acetate- $\beta \mathrm{Na}$ and on propionate- $\alpha \mathrm{Na}$. $E_{2}$ was active on the 3 substrates, with a noticeable higher activity on butyrate- $\alpha \mathrm{Na}$. In contrast, $E_{3}$ was not active on acetate$\beta \mathrm{Na}$, showing a strong activity on propionate- $\alpha \mathrm{Na}$ and, for CIP 103026 on butyrate$\alpha \mathrm{Na}$. Moreover, another minor active band $\left(R_{\mathrm{f}} 0.40\right)$ was present in CIP 103026. 
Table II. Esterase electrophoretic patterns of intracellular fractions of the different species of dairy Propionibacterium.

Profils électrophorétiques des activités estérasiques des fractions intracellulaires d'espèces de bactéries propioniques laitières.

\begin{tabular}{|c|c|c|c|c|c|}
\hline \multirow[t]{3}{*}{ Strains } & \multirow[t]{3}{*}{ Band } & \multirow[t]{3}{*}{$R_{f}$} & \multicolumn{3}{|c|}{ Intensity of esterasic activity a } \\
\hline & & & \multicolumn{3}{|c|}{ Substrates } \\
\hline & & & Acetate- $\beta \mathrm{Na}$ & Propionate- $\alpha \mathrm{Na}$ & Butyrate- $\alpha \mathrm{Na}$ \\
\hline \multicolumn{6}{|c|}{$P$ freudenreichii CIP 103026} \\
\hline & $\mathrm{E}_{1}$ & 0.85 & +++ & +++ & - \\
\hline & $E_{2}$ & 0.63 & ++ & ++ & +++ \\
\hline & $\mathrm{E}_{3}$ & 0.47 & - & - & ++ \\
\hline & $\mathrm{E}_{4}$ & 0.40 & - & - & + \\
\hline \multicolumn{6}{|c|}{ P shermanii CIP 103027} \\
\hline & $\mathrm{E}_{1}$ & 0.85 & +++ & +++ & - \\
\hline & $E_{2}$ & 0.62 & ++ & ++ & +++ \\
\hline & $\mathrm{E}_{3}$ & 0.47 & - & + & - \\
\hline \multicolumn{6}{|c|}{ P jensenii CIP 103028} \\
\hline & $E_{4}$ & 0.40 & ++ & ++ & ++ \\
\hline \multicolumn{6}{|c|}{$P$ thoenii CIP 103029} \\
\hline & $E_{5}$ & 0.50 & - & + & + \\
\hline & $E_{4}$ & 0.40 & +++ & +++ & +++ \\
\hline \multicolumn{6}{|c|}{$P$ acidipropionici DSM 4900} \\
\hline & $\mathrm{E}_{6}$ & 0.78 & ++ & +++ & +++ \\
\hline & $E_{7}$ & 0.43 & ++ & +++ & +++ \\
\hline
\end{tabular}

a Intensity was expressed by: -: no activity; from + to +++: from a thin to a deep-coloured band.

a L'intensité des bandes actives est représentée par : - : pas de bandes actives; de + $\mathbf{a}+++$ : bandes faiblement à fortement colorées.

- $P$ jensenii and $P$ thoenii electrophoretic patterns were very similar. CIP 103028 and CIP 103029 had a common esterase activity $E_{4}$ with a broad substrate specificity. In addition, another active band $\left(R_{f}\right.$ 0.50 ) on propionate- and butyrate- $\alpha \mathrm{Na}$, was shown by the $P$ thoenii strain.

- A singular esterase pattern was shown by $P$ acidipropionici DSM 4900: 2 bands $\left(R_{\mathrm{f}} 0.78\right.$ and 0.43 ) were revealed with a broad substrate specificity.

None of the strains presented an active band for longer chain length substrates than butyrate- $\alpha \mathrm{Na}$ (valerate- $\alpha \mathrm{Na}$, caproate- $\alpha \mathrm{Na}$, caprylate- $\alpha \mathrm{Na}$, caprate- $\alpha \mathrm{Na}$, laurate- $\alpha \mathrm{Na}$, myristate- $\alpha \mathrm{Na}$, palmitate$\alpha \mathrm{Na}$, stearate- $\beta \mathrm{Na})$.

\section{Purification stage}

Ion-exchange chromatography of the intracellular fraction of $P$ freudenreichii subsp freudenreichii CIP 103026 led to the elution of 3 main fractions presenting esterase activities (fig 2). The first fraction, elut- 


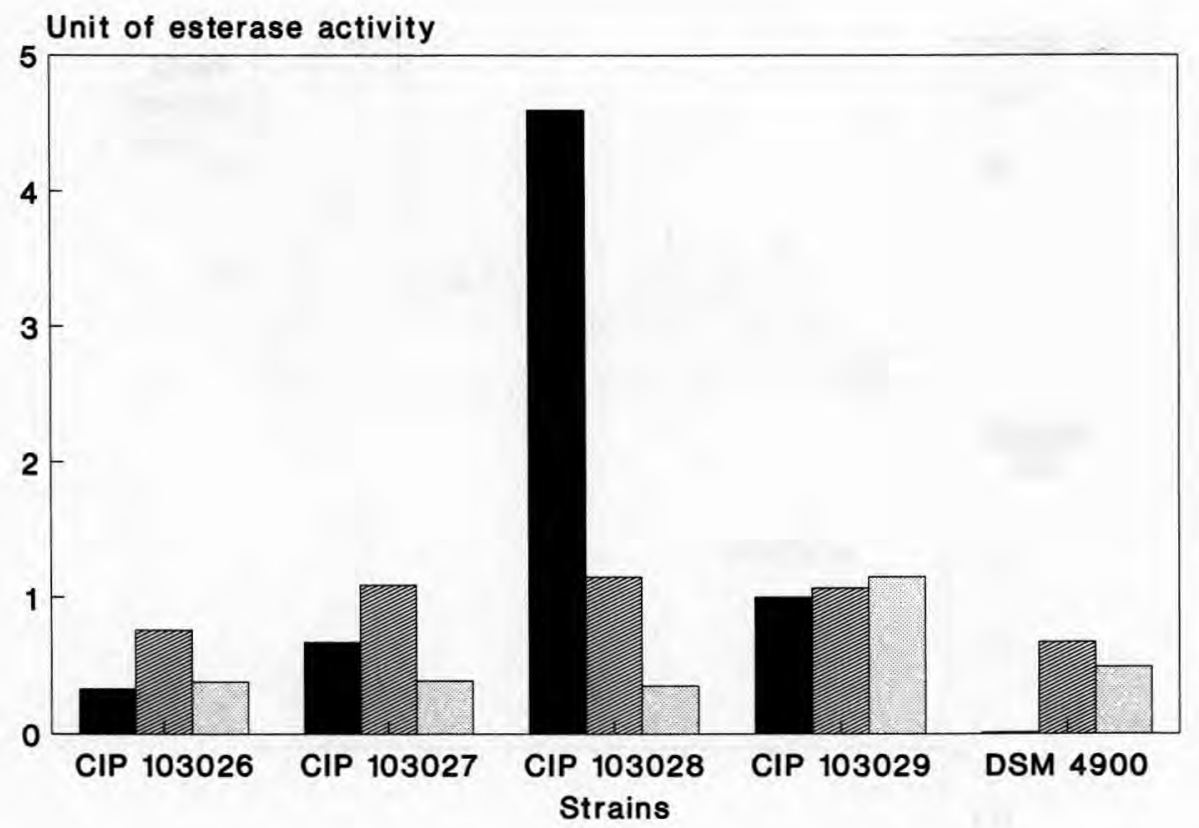

Fig 1. Esterase activity of intracellular fractions of dairy Propionibacterium species. A unit of specific esterase activity was defined as the change of 0.1 unit absorbance $(540 \mathrm{~nm})$ per min and per $\mathrm{mg}$ bac-

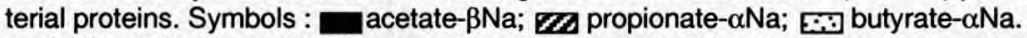

Activités estérasiques des fractions intracellulaires d'espèces de bactéries propioniques laitières. Une unité d'activité spécifique était définie par la variation de 0,1 unité d'absorbance $(540 \mathrm{~nm})$ par min et pour $1 \mathrm{mg}$ de protéines microbiennes. Symboles : acetate- $\beta \mathrm{Na}$; $\mathbb{Z}$ propionate- $\alpha \mathrm{Na}$; butyrate- $\alpha \mathrm{Na}$.

ed at $0.19 \mathrm{~mol}^{-1} \mathrm{I}^{-1} \mathrm{NaCl}$, was strongly active on acetate- $\beta \mathrm{Na}$ and propionate- $\alpha \mathrm{Na}$, with respective activity values of 0.074 and $0.160 \mathrm{U}$, whereas only a slight activity of $0.004 \mathrm{U}$ was found on butyrate- $\alpha \mathrm{Na}$. A second fraction which was only active on butyrate- $\alpha \mathrm{Na}$, was eluted at $0.25 \mathrm{~mol} \cdot \mathrm{I}^{-1}$ $\mathrm{NaCl}$. Finally, the third fraction, which was strongly active on the 3 substrates, appeared at $1 \mathrm{~mol} \cdot \mathrm{I}^{-1} \mathrm{NaCl}$.

\section{DISCUSSION}

In this study, using the API ZYM system Propionibacteria were revealed to be ac- tive on many substrates with various specificities depending on substrates. The use of this technique has been recommended by Arora et al (1990) for assessment of bacterial enzymatic potential. No evidence of the esterase system localization could be found, even if activities seemed to be stronger in intracellular fractions.

Esterase systems have already been described in many bacterial species (Morichi et al 1968; Harper et al, 1980; El Soda et al, 1986a,b; Kamaly et al, 1988; Bhowmik and Marth, 1990; Khalid et al, 1990; Tsakalidou and Kalantzopoulos, 1992). Only a few studies on esterase of dairy Propionibacterium species can be found in 

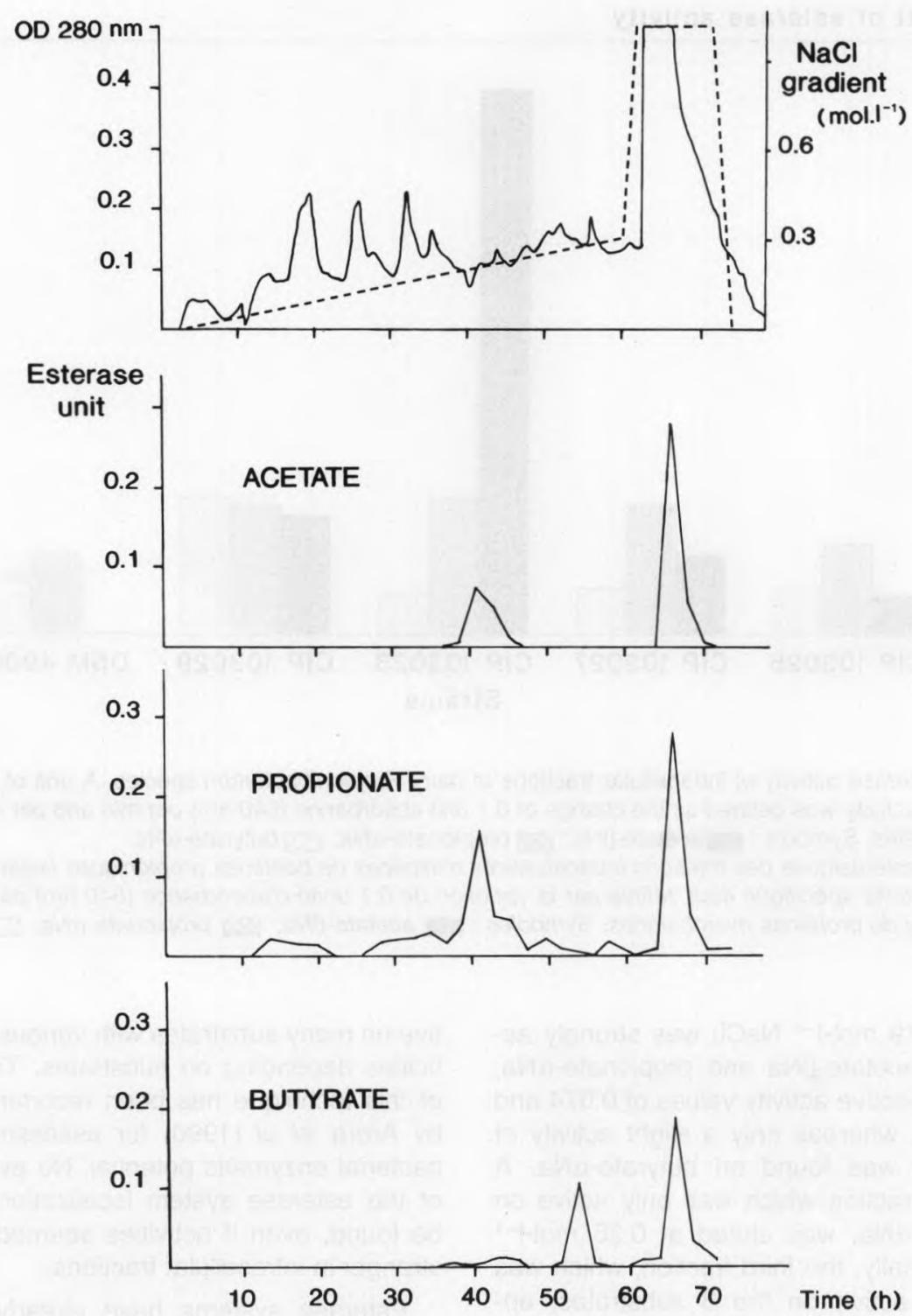

Fig 2. Ion-exchange purification stage of intracellular fraction of $P$ freudenreichii subsp freudenreichii CIP 103026. Esterase activity was tested using acetate- $\beta \mathrm{Na}$, propionate- $\alpha \mathrm{Na}$ and butyrate$\alpha \mathrm{Na}$. A unit of esterase activity was defined as the change in 0.1 unit absorbance $(540 \mathrm{~nm})$ per min. Séparation des différentes activités estérasiques, par chromatographie d'échange d'ions, de la fraction intracellulaire de $\mathrm{P}$ freudenreichii subsp freudenreichii CIP 103026. Les activités estérasiques étaient testées sur acétate- $\beta \mathrm{Na}$, propionate- $\alpha \mathrm{Na}$ et butyrate- $\alpha \mathrm{Na}$. Une unité d'activité estérasique était définie comme le changement de 0.1 unité d'absorbance par min. 
the literature. In 2 short congress abstracts, El Soda et al (1984) and Ezzat et al (1992) mentioned esterase activity respectively in $P$ freudenreichii and $P$ acidipropionici, but unfortunately without any detail. Oterholm et al (1970b) suggested the existence of both an esterase and a lipase in $P$ freudenreichii subsp shermanii, but finally concluded that these 2 activities were only due to a true lipase. Nevertheless, esterase activity has not been researched systematically.

The intracellular fraction activities of Propionibacterium showed various substrate specificities. This has already been described in other bacterial species (EI Soda et al, 1986a; Bhowmik and Marth, 1990; Khalid et al, 1990). El Soda et al (1986b), working on strains of Lactobacillus helveticus, $L$ bulgaricus, $L$ lactis and $L$ acidophilus found different patterns of activity depending on the chain length substrates, even for strains of the same species. $L$ helveticus CNRZ 303 and CNRZ 223 had decreased activity with rising chain length, whereas CNRZ 243 showed the opposite trend; the highest activity was shown by CNRZ 244 on propionate nitrophenyl derivatives. Those 2 trends were found in the 5 strains of Propionibacterium of this study. Moreover. El Soda et al (1986a) and Bhowmik and Marth (1990) pointed out the importance of the substrate structure: lactobacilli preferentially hydrolyzed $p$-nitrophenyl derivatives rather than o-nitrophenyl derivatives. Thus, differences between specific activity values must be interpreted with care. Estimation of the esterase potential of a strain (before industrial use, for example) should at least be made on more than one substrate.

Activities on substrates from acetate to caprate were found when using API ZYM systems. However, these activities could not be confirmed quantitatively in intracellular fractions. Under our operating conditions, substrates such as valerate- $\mathrm{BNa}$ were not easily soluble, resulting in opalescent solutions which are not usable in a colorimetric method. Thus, esterase systems of Propionibacterium may be more extended. The adsorbed substrate in the API ZYM system is probably more efficient, but esterase activity must normally act on substrate in solution. In order to solubilize longer chain length substrates, some authors enhance the acetone concentration in the medium. But this technique very often leads to a loss of enzyme activity. Gomori (1953) has suggested the use of 1,2-propanediol to better solubilize the long fatty acid derivatives. Using this technique was successful for myristate$\alpha \mathrm{Na}$ but failed for palmitate- $\alpha \mathrm{Na}$ and stearate- $\beta \mathrm{Na}$, which gave unstable opalescent solutions. Unfortunately no activity was revealed with the myristate solution with $P$ freudenreichii subsp freudenreichii CIP 103026 intracellular fraction. The use of microemulsions to reveal esterolytic (or lipolytic) activity on substrates with a chain length $>5$ carbons seems to be a very useful method, even if this technique is still difficult to handle (Haering et al, 1987).

The complexity of the esterase system was demonstrated using PAGE separation, but on the 5 tested species, only 3 different patterns were shown. Strains of $P$ freudenreichii had different patterns from those of $P$ thoenii/P jensenii and $P$ acidipropionici. The subspecies shermanii and freudenreichii could not be distinguished, neither could be strains of $P$ thoenii or $P$ jensenii. However, esterase electrophoretic patterns remain a useful tool to differentiate Propionibacterium species. This has already been pointed out in the literature for other bacterial species (Lund, 1965; Goullet, 1977). Morichi et al (1968) were able to distinguish different species of streptococci and other lactic acid bacteria by this mean. El Soda et al (1986a, b) and Kamaly et al (1988) also highlighted the usefulness of this technique to classify 
strains of Lactobacillus and Streptococcus.

Species of Propionibacterium can be differentiated by electrophoresis of their total proteins (Baer, 1987), but this technique is very difficult to handle because of the complexity of the patterns obtained. The revelation of their enzyme activities after electrophoresis could be useful, but not totally discriminant in the identification of propionibacteria after the systematic study of a higher number of strains. Nevertheless, it has been shown that some esterases are active only on a few substrates. This is in accordance with Tsakalidou et al (1992): Lactococcus lactis subsp lactis ACA-DC 128 showed 2 esterases when using acetate- $\alpha \mathrm{Na}$, but 3 when butyrate$\alpha$ Na was used. Thus, it would be more reliable to check the identity of Propionibacterium with acetate, propionate and butyrate naphthyl derivatives. In this study we did not try to show potential variation in activity between $\alpha$ and $\beta$ naphthyl derivatives. This will be carried out on the purified enzymes.

No activity was found when longer chain length substrates were used. But, as emphasized Morichi et al (1968), this does not mean that esterases are inactive on these substrates. Longer substrates may have difficulty in reaching the enzyme in the polyacrylamide gel.

The partial purification of the intracellular fraction of $P$ freudenreichii subsp freudenreichii CIP 103026 yielded 3 esterases which were differentiated by their elution time and their substrate specificity. These results agree with the esterase electrophoretic pattern: the first eluted esterase was strongly active on acetate- $\beta \mathrm{Na}$ and propionate- $\alpha \mathrm{Na}$, as was the electrophoretic esterase $E_{1}$. The second was only active on butyrate- $\alpha \mathrm{Na}$, as was the electrophoretic esterase $E_{3}$ and the third was active onto the 3 substrates as was esterase $E_{2}$. However, a longer elution gradient must be ap- plied to attempt a possible separation of the last esterase which was eluted at $1 \mathrm{~mol}^{\circ-1} \mathrm{NaCl}$ into different fractions. Nevertheless, the current separation enabled us to independently study these 3 main esterase activities.

The proportion of free fatty acids other than propionic and acetic acids found in Swiss cheese is very similar to that of fatty acids in milk fat (Langler and Day, 1966). This suggests the existence of a lipolytic breakdown of milk fat, mainly of microbial origin, for cheeses made with pasteurized milk in which the natural lipase of the milk is destroyed. Apart from the use of esterases in identification, it seems important to further study their number, their substrate specificity and their activity level. These points appear essential for a better understanding of propionibacteria, one of the main ripening flora of this type of cheese.

\section{ACKNOWLEDGMENTS}

The authors are grateful to R Talon for helpful discussions, to $\mathrm{JL}$ Maubois and F Girard for their comments on the manuscript. This work was supported by grants from the Région Bretagne. One of us (CD) is greatly indebted to INRA and the Région Bretagne for being awarded a doctoral scholarship.

\section{REFERENCES}

Arora G, Lee BH, Lamoureux M (1990) Characterization of enzyme profiles of Lactobacillus casei species by a rapid API ZYM system. $J$ Dairy Sci 73, 264-273

Baer A (1987) Identification and differentiation of propionibacteria by electrophoresis of their proteins. Milchwissenschaft 42, 431-433

Bhowmik T, Marth EH (1990) Esterases of Micrococcus species: identification and partial characterization J Dairy Sci 73, 33-40

Biede SL, Paulsen PV, Hammond EG, Glatz BA (1979) The flavor of Swiss cheese. Dev Ind Microbiol 20, 203-215 
Boyaval P, Corre C (1987) Continuous fermentation of sweet whey permeate for propionic acid production in a CSTR with UF recycle. Biotechnol Lett 9, 801-806

Cantoni C, Molnar MR, Renon P (1966) Richerche sull' azione lipolitica dei batteri propionici. Arch Vet Ital 17, 335-342

Cummins CS, Johnson JL (1986) Propionibacterium. In: Bergey's Manual of Systematic Bacteriology (Sneath PH, Mair NS, Sharpe HE, Holt JG, eds) Williams and Wilkins, Baltimore, vol 2, 1346-1353

El Soda M, Ziada N, Ezzat N, Ismail A (1984) The proteolytic and lipolytic activities of Propionibacterium freudenreichii. J Dairy Sci 67 (suppl 1), 86

El Soda M, Fathallah S, Ezzat N, Desmazeaud MJ, Abou Donia S (1986a) The esterolytic and lipolytic activities of lactobacilli. Detection of the esterase systems of Lactobacillus casei, Lactobacillus plantarum, Lactobacillus brevis and Lactobacillus fermentum. Sci Aliments 6, 545-557

El Soda M, Abd El Wahab H, Ezzat N, Desmazeaud MJ, Ismail A (1986b) The esterolytic and lipolytic activities of the lactobacilli. II. Detection of the esterase system of Lactobacillus helveticus, Lactobacillus bulgaricus, Lactobacillus lactis and Lactobacillus acidophilus. Lait $66,431-443$

Ezzat N, El Soda M, El Shafei H (1992) Cell-wall associated peptide hydrolases and esterases of some cheese related bacteria. J Dairy Sci 75 (suppl 1), 95

Goldberg JA, Rutenburg AM (1958) The colorimetric determination of leucine aminopeptidase in urine and serum of normal subjects and patients with cancer and other diseases. Cancer 11, 283-291

Gomori G (1953) Human esterases. J Lab Clin Med 42, 445-453

Goullet P (1977) Relationships between electrophoretic patterns of esterases from Salmonella. J Gen Microbio/ 98, 535-542

Haering G, Pessina A, Meussdoeffer F, Hochkoeppler S, Luisi PL (1987) Solubilization of bacterial cells in organic solvents via reverse micelles and microemulsions. Ann NY Acad Sci 506, 337-343

Harper WJ, Carmona de Catril A, Chen JL (1980) Esterases of lactic streptococci and their stability in cheese slurry systems. Milchwissenschaft $35,129-132$

Hettinga DH, Reinbold GW (1972) The propionic-acid bacteria-a review. III. Miscellaneous metabolic activities. J Milk Food Technol 35, 436-447

Kaderavek G, Carini S, Saccinto I (1973) Azione delle lipasi microbiche sul grasso del latte. Riv Ital Sostanze Grasse 50, 135-136

Kamaly KM, El Soda M, Marth EH (1988) Esterolytic activity of Streptococcus lactis, Streptococcus cremoris and their mutants. Milchwissenschaft 43, 346-349

Khalid NM, El Soda M, Marth EH (1990) Esterases of Lactobacillus helveticus and Lactobacillus delbrueckii ssp bulgaricus. J Dairy Sci 73, 2711-2719

Knaut T, Mazurek K (1974) Caractères lipolytiques des bactéries propioniques. In: XIX Int Dairy Congr B6, 425

Langler JE, Day EA (1966) Quantitative analysis of the major free fatty acids in Swiss cheese. $J$ Dairy Sci 49, 91-93

Lawrence RC (1967) Microbial lipases and related esterases. Dairy Sci Abstr 29, 1-8, 59-70

Lowry OH, Rosebrough NJ, Farr AL, Randall RJ (1951) Protein measurement with the folin phenol reagent. J Biol Chem 193, 265-275

Lund BM (1965) A comparison by the use of gel electrophoresis of soluble protein components and esterase of some group D streptococci. J Gen Microbiol 40, 413-419

Malik AC, Reinbold GW, Vedamuthu ER (1968) An evaluation of the taxonomy of Propionibacterium. Can J Microbiol 14, 1185-1191

Morichi T, Sharpe ME, Reiter B (1968) Esterases and other soluble proteins of some lactic acid bacteria. J Gen Microbiol 53, 405-414

Ohren JA, Tuckey SL (1965) Relation of fat hydrolysis to flavor development in Cheddar cheese. J Dairy Sci 48, 765

Oterholm A (1967) Glycerol ester hydrolases of some lactic and propionic acid bacteria. Ph D Thesis, Univ Illinois, Urbana, USA

Oterholm A, Ordal ZJ, Witter LD (1970a) Glycerol ester hydrolase activity of Propionibacterium shermanii. J Dairy Sci 53, 592-593

Oterholm A, Ordal ZJ, Witter LD (1970b) Purification and properties of a glycerol ester hydrolase (lipase) from Propionibacterium shermanii. Appl Microbiol 20, 16-22 
Tsakalidou E, Kalantzopoulos G (1992) Purification and partial characterization of an esterase from Lactococcus lactis ssp lactis strain ACA-DC 127. Lait 72, 533-543

Tsakalidou $E$, Zoidou $E$, Kalantzopoulos G (1992) Esterase activities of cell-free extracts from strains of Lactococcus lactis subsp lactis isolated from traditional Greek cheese. J Dairy Res 59, 111-113

Umanskii MS, Matveeva EK, Borovkova YuA, Ostroumov LA (1974) Étude comparée des mé- thodes de détermination de l'activité glycérol ester hydrolase des bactéries lactiques et propioniques. In: XIX Int Dairy Congr B5, 367-368

Umanskii MS, Borovkova YUA (1979) Lipolytic activity of lactic and propionic bacteria. Molochn Prom 6, 20-23,46

Werner H (1967) Untersuchungen über die Lipase und Lecithinase Aktivität von aeroben und anaeroben Corynebacterium und von Propionibacterium Arten. Zentralbl Bakteriol Parasitenkd 204, 127-138 